\title{
Antibacterial Activities of Metabolites from Platanus occidentalis (American sycamore) against Fish Pathogenic Bacteria
}

\author{
Kevin K Schrader ${ }^{1 *}$, Mark T Hamann²,3, James D McChesney ${ }^{4}$, Douglas L Rodenburg ${ }^{4}$, and Mohamed A Ibrahim ${ }^{1,2,5}$ \\ ${ }^{1}$ United States Department of Agriculture, Agricultural Research Service, Natural Products Utilization Research Unit, National Center for Natural Products Research, Post \\ Office Box 1848, Mississippi 38677, USA \\ ${ }^{2}$ Departments of Pharmacognosy, School of Pharmacy, University of Mississippi, University, Mississippi 38677, USA \\ ${ }^{3}$ Pharmacology, Chemistry and Biochemistry Department, School of Pharmacy, University of Mississippi, University, Mississippi 38677, USA \\ ${ }^{4}$ Ironstone Separations, Inc., 147 County Road 245, Etta, Mississippi 38627, USA \\ ${ }^{5}$ Department of Chemistry of Natural Compounds, National Research Center, Dokki 12622, Cairo, Egypt
}

\begin{abstract}
One approach to the management of common fish diseases in aquaculture is the use of antibiotic-laden feed. However, there are public concerns about the use of antibiotics in agriculture and the potential development of antibiotic resistant bacteria. Therefore, the discovery of other environmentally safe natural compounds as alternatives to antibiotics would benefit the aquaculture industries. Four natural compounds, commonly called platanosides, [kaempferol 3-O- $\alpha$-L-(2",3"-di-E- $p$-coumaroyl)rhamnoside (1), kaempferol 3-O- $\alpha$-L-(2"-E- $p$-coumaroyl$3 "-Z$ - $p$-coumaroyl)rhamnoside (2), kaempferol 3-O- $\alpha$-L-(2"-Z- $p$-coumaroyl-3"-E-p-coumaroyl)rhamnoside (3), and kaempferol 3-O- $\alpha$-L-(2",3"-di-Z- $p$-coumaroyl)rhamnoside (4)] isolated from the leaves of the American sycamore (Platanus occidentalis) tree were evaluated using a rapid bioassay for their antibacterial activities against common fish pathogenic bacteria including Flavobacterium columnare, Edwardsiella ictaluri, Aeromonas hydrophila, and Streptococcus iniae. The four isomers and a mixture of all four isomers were strongly antibacterial against isolates of $F$. columnare and S. iniae. Against F. columnare ALM-00-173, $\mathbf{3}$ and $\mathbf{4}$ showed the strongest antibacterial activities, with $24-\mathrm{h} 50 \%$ inhibition concentration $\left(\mathrm{IC}_{50}\right)$ values of $2.13 \pm 0.11$ and $2.62 \pm 0.23 \mathrm{mg} / \mathrm{L}$, respectively. Against $S$. iniae LA94-426, 4 had the strongest antibacterial activity, with $24-\mathrm{h} I \mathrm{IC}_{50}$ of $1.87 \pm 0.23 \mathrm{mg} / \mathrm{L}$. Neither a mixture of the isomers nor any of the individual isomers were antibacterial against isolates of $E$. ictaluri and $A$. hydrophila at the test concentrations used in the study. Several of the isomers appear promising for the potential management of columnaris disease and streptococcosis in fish.
\end{abstract}

Keywords: Antibacterial; Channel catfish; Columnaris disease; Flavobacterium columnare; Kaempferol; platanoside; Streptococcosis; Streptococcus iniae; Sycamore

\section{Introduction}

Common bacterial diseases of pond-raised channel catfish (Ictalurus punctatus) in the southeastern United States include columnaris disease and enteric septicemia of catfish (ESC). Columnaris disease-related problems also occur world-wide in many other species of freshwater fish (e.g., rainbow trout, salmon, and tilapia), and this disease can result in heavy economic losses to these aquaculture industries [1,2]. The etiological agent for columnaris disease is the bacterium Flavobacterium columnare which is a Gram-negative motile rod (2-10 $\mu \mathrm{m}$ in length) in the family Flavobacteriaceae [3]. Columnaris disease can result in severe necrosis of gill tissue, skin ulceration from systemic infection, and high mortalities in fish. The etiological agent for ESC is the bacterium Edwardsiella ictaluri which is a Gram-negative weakly motile rod (1-3 $\mu \mathrm{m}$ in length) and in the family Enterobacteriaceae [2]. The gross lesions of ESC in channel catfish can include pale gills, small depigmented lesions and/or ulcers (1-3 $\mathrm{mm})$ on the backs of infected fish, open lesions along the central skull line between the eyes, and hemorrhage at the base of the fins, under the jaw, and on the belly. High mortality rates of channel catfish and prevention and treatment approaches can cost producers millions of dollars annually [2].

Bacterial diseases also adversely impact the aquaculture of sunshine bass, Morone chrysops female $\times$ Morone saxatilis male. Sunshine bass production has been the fastest growing segment of the aquaculture industry in the United States over the past decade and has spread to several countries in Europe and Asia $[4,5]$. However, sunshine bass production has been plagued by many pathogens including
Aeromonas hydrophila and F. columnare [2]. A. hydrophila is a Gramnegative short, motile rod, ubiquitous in the aquatic environment, and the agent responsible for motile Aeromonas septicemia (MAS) in fish. Both A. hydrophila and F. columnare typically act as secondary pathogens causing significant losses in fish populations in the presence of predisposing stressors. These two pathogens can also act as primary pathogens, requiring no predisposing conditions to inflict significant mortalities [2].

Another bacterial disease which can cause losses of farmed freshwater fish is streptococcosis which is a prevalent problem in fish species such as tilapias (Oreochromis spp.) and hybrid striped bass [Morone chrysops female $\times$ Morone saxatilis male (Percichthyidae)] [6]. One of several streptococcal bacteria that has been attributed as the cause of streptococcosis in freshwater fish is Streptococcus iniae which is a Gram-positive spherical-shaped cell $(0.5-2.0 \mu \mathrm{m}$ in diameter). In

*Corresponding author: Kevin Schrader, United States Department of Agriculture, Agricultural Research Service, Natural Products Utilization Research Unit, National Center for Natural Products Research, Post Office Box 1848, University, Mississippi 38677, USA, Tel: +1662-915-1144; Fax: +1662-915-1035; E-mail: kevin.schrader@ars.usda.gov

Received August 17, 2015; Accepted September 17, 2015; Published October 15, 2015

Citation: Schrader KK, Hamann MT, McChesney JD, Rodenburg DL, Ibrahim MA (2015) Antibacterial Activities of Metabolites from Platanus occidentalis (American sycamore) against Fish Pathogenic Bacteria. J Aquac Res Development 6: 364 doi:10.4172/2155-9546.1000364

Copyright: (C) 2015 Schrader KK, et al. This is an open-access article distributed under the terms of the Creative Commons Attribution License, which permits unrestricted use, distribution, and reproduction in any medium, provided the original author and source are credited. 
Citation: Schrader KK, Hamann MT, McChesney JD, Rodenburg DL, Ibrahim MA (2015) Antibacterial Activities of Metabolites from Platanus occidentalis (American sycamore) against Fish Pathogenic Bacteria. J Aquac Res Development 6: 364. doi:10.4172/2155-9546.1000364

tilapia, gross lesions of streptococcosis include hemorrhaging in the skin and at the base of fins, epidermal lesions and/or bloody ulcers, and opaque corneas [2]. Streptococcosis in a fish population can result in very high mortality rates, and therefore management approaches include prevention as well as treatment once the disease is determined to be present.

Catfish producers may use several currently available management approaches for columnaris disease or ESC including the application of medicated feeds [oxytetracycline dihydrate (Terramycin; Phibro Animal Health, Teaneck, NJ, USA) for ESC and florfenicol (Aquaflor; Intervet Inc., Millsboro, DE, USA) for columnaris disease and ESC], live attenuated vaccines [7], and nonantibiotic therapeutants such as 35\% Perox-Aid for external columnaris [2]. However, Perox-Aid is not recommended for use in earthen ponds without water exchange. Additional inorganic agents such as copper sulfate pentahydrate $\left(\mathrm{CuSO}_{4} .5 \mathrm{H}_{2} \mathrm{O}\right)$ and potassium permanganate $\left(\mathrm{KMnO}_{4}\right)$ have been cited as potential treatments for columnaris disease [8], but the efficacy of these compounds can be adversely impacted by some water quality variables. Also, extra care must be used when utilizing these therapeutants due to their broad-spectrum toxicity towards non-target organisms such as channel catfish [9].

At present, there are no approved drugs for the treatment of MAS caused by $A$. hydrophila in sunshine bass. Recent studies examining the use of $\mathrm{CuSO}_{4} \cdot 5 \mathrm{H}_{2} \mathrm{O}, \mathrm{KMnO}_{4}$, and Aquaflor ${ }^{\circ}$ have noted the potential efficacy of using these compounds to manage MAS in fish $[10,11]$. The use of Aquaflor with $\mathrm{CuSO}_{4} \cdot 5 \mathrm{H}_{2} \mathrm{O}$ to manage mixed infections of $A$. hydrophila and $F$. columnare in sunshine bass appears to be especially promising [10], but future studies in ponds are still required to confirm this approach.

Preventive management approaches for streptococcosis include maintaining high water quality, the application of high-quality diets, adequate water exchange and disinfection, and the removal of fecal waste from recirculating water systems [2]. Currently, only florfenicol (Aquaflor ${ }^{\circledast}$ ) is approved in the United States for the treatment of streptococcal septicemia caused by $S$. iniae in warmwater fish. Vaccination appears to be a promising approach for protection against S. iniae infection in Nile tilapia [12].

The discovery of novel, environmentally safe, natural antibacterial compounds would benefit aquaculturists due to the current limitations or the absence of efficacious management approaches available to producers for controlling the bacterial species responsible for columnaris disease, ESC, MAS, and streptococcosis. As part of our discovery process to identify active compounds against isolates of $F$. columnare, E. ictaluri, A. hydrophila, and S. iniae, natural compounds (Figure 1) from the American sycamore (Plantus occidentalis L. family Platanaceae) previously identified as antibacterial against methicillinresistant Staphylococcus aureus (MRSA) [13] were evaluated in a rapid bioassay.

\section{Materials and Methods}

\section{Test compounds}

Four isolated compounds obtained from the leaves of the common American sycamore (P. occidentalis) were provided by Ironstone Separations, Inc., Etta, MS, USA. These four compounds were previously identified [13] as the following: kaempferol 3-O- $\alpha-$ L-(2",3"-di-E-p-coumaroyl)rhamnoside (1), kaempferol 3-O- $\alpha$-L(2"-E-p-coumaroyl-3"-Z-p-coumaroyl)rhamnoside (2), kaempferol 3-O- $\alpha$-L-(2"-Z-p-coumaroyl-3"-E-p-coumaroyl)rhamnoside (3), and kaempferol 3-O- $\alpha$-L-(2",3"-di-Z-p-coumaroyl)rhamnoside (4). A test mixture (Mix) of all four isomers (approximately 33\% 1, 23\% 2, 26\% 3 , and $19 \%$ 4) was also evaluated. The purity of each of the four test compounds and Mix was $>95 \%$.

\section{Microorganisms and preparation of culture material for bio- assay}

An isolate of F. columnare [isolate ALM-00-173 (genomovar II)] was obtained from Dr. Covadonga Arias (Department of Fisheries and Allied Aquacultures, Auburn University, Auburn, AL, USA). Cultures of $F$. columnare ALM-00-173 were maintained separately on modified Shieh (MS) agar plates ( $\mathrm{pH}$ 7.2-7.4) [14] in order to assure purity. Prior to conducting the bioassay, single colonies of $F$. columnare ALM-00173 were utilized in the preparation of the assay culture material by culturing in $75 \mathrm{~mL}$ of MS broth for $24 \mathrm{~h}$ at $29 \pm 1{ }^{\circ} \mathrm{C}$ at $150 \mathrm{rpm}$ on a rotary shaker (model C24KC; New Brunswick Scientific, Edison, NJ, USA). After overnight incubation, a 0.5 McFarland standard of $F$. columnare ALM-00-173 culture material was prepared by transferring cells from the broth culture to fresh MS broth [15].

An isolate of E. ictaluri (isolate S02-1039) was obtained from Mr. Tim Santucci (formerly with the College of Veterinary Medicine, Mississippi State University, Stoneville, MS, USA). Cultures of E. ictaluri were maintained on 3.8\% Mueller-Hinton (MH) agar plates (pH 7.3) (Becton, Dickinson and Company, Sparks, Maryland) in order to assure purity. Prior to conducting the bioassay, single colonies of $E$. ictaluri S02-1039 were utilized in the preparation of the assay culture material by aseptically transferring bacterial cells from colonies to 45 $\mathrm{mL}$ of $3.8 \% \mathrm{MH}$ broth to form a bacterial cell density of $0.5 \mathrm{McF}$ arland standard.

An isolate of $A$. hydrophila (isolate HSB-B2) was provided by Dr. Julie Bebak (formerly with the U.S. Department of Agriculture, Agricultural Research Service, Aquatic Animal Health Research

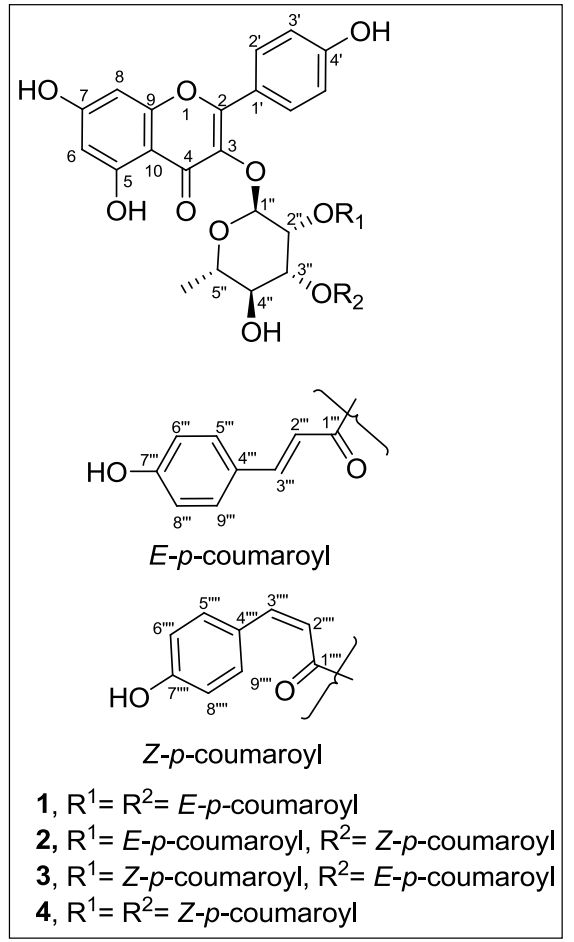

Figure 1: The structures of American sycamore glycosides 1-4. 
Citation: Schrader KK, Hamann MT, McChesney JD, Rodenburg DL, Ibrahim MA (2015) Antibacterial Activities of Metabolites from Platanus occidentalis (American sycamore) against Fish Pathogenic Bacteria. J Aquac Res Development 6: 364. doi:10.4172/2155-9546.1000364

Laboratory, Auburn, AL, USA), and this isolate was obtained from sunshine bass that had died during a farm outbreak. To ensure culture purity, A. hydrophila HSB-B2 was streaked on MH agar plates. Prior to conducting the bioassay, single colonies of A. hydrophila HSB-B2 were used to prepare the assay culture material by culturing $A$. hydrophila HSB-B2 in $50 \mathrm{~mL}$ of $3.8 \% \mathrm{MH}$ broth at $29 \pm 1^{\circ} \mathrm{C}$ at $150 \mathrm{rpm}$ on a rotary shaker for $18 \mathrm{~h}$ in order to prepare the $0.5 \mathrm{MacFarland}$ standard.

A culture of $S$. iniae (isolate LA94-426) was provided by Dr. Ahmed Darwish (formerly with the U.S. Department of Agriculture, Agricultural Research Service, Harry K. Dupree Stuttgart National Aquaculture Research Center, Stuttgart, AR, USA). In order to assure purity, cultures of $S$. iniae LA94-426 were maintained on plates of Columbia CNA agar containing 5\% sheep blood (Remel, Inc., Lenexa, KS, USA). The bioassay culture material of $S$. iniae LA94-426 was prepared in the same manner as used for F. columnare ALM-00-173, except 3.8\% MH broth was used and the broth cultures were incubated for $18 \mathrm{~h}$ prior to preparing the $0.5 \mathrm{MacF}$ arland standard.

\section{Antibacterial bioassay}

The test compounds were evaluated for antibacterial activity using a rapid 96-well microplate bioassay and following previous procedures [15]. Florfenicol and oxytetracycline $\mathrm{HCl}$ were included as positive drug controls. Control wells (no test material added) were also included in each assay. Test compounds and drug controls were dissolved separately in technical grade $100 \%$ ethanol. Final concentrations of test compounds and drug controls were $0.01,0.1,1.0,10.0$, and $100.0 \mu \mathrm{M}$. Three replications were used for each dilution of each test compound and controls. Final results were converted to units of $\mathrm{mg} / \mathrm{L}$ to allow comparison with previous studies.

The 24-h 50\% inhibition concentration $\left(\mathrm{IC}_{50}\right.$ ) and minimum inhibitory concentration (MIC) were determined using sterile 96-well polystyrene microplates (Corning Costar Corp., Acton, Massachusetts) with flat-bottom wells. Initially, dissolved test compounds or drug controls were micropippeted separately into individual microplate wells $(10 \mu \mathrm{L} /$ well $)$, and the ethanol was allowed to completely evaporate before $0.5 \mathrm{MacFarland}$ bacterial culture was added to the microplate wells $\left(200 \mu \mathrm{L} /\right.$ well). Microplates were incubated at $29 \pm 1^{\circ} \mathrm{C}$ (VWR model 2005 incubator; Sheldon Manufacturing, Inc., Cornelius, OR, USA). A Packard model SpectraCount microplate photometer (Packard Instrument Company, Meriden, CT, USA) was used to measure the absorbance $(630 \mathrm{~nm})$ of the microplate wells at time 0 and $24-\mathrm{h}$.

The means and standard deviations of absorbance measurements were calculated, graphed, and compared to controls to determine the 24-h IC IC $_{50}$ and MIC for each test compound. The 24-h IC Fn $_{50}$ and MIC results for each test compound were divided by the respective $24-\mathrm{h}$ $\mathrm{IC}_{50}$ and MIC results obtained for the positive controls florfenicol and oxytetracycline to determine the relative-to-drug-control florfenicol (RDCF) and relative-to-drug-control oxytetracycline (RDCO) values.

\section{Results and Discussion}

Among the four isomers of the sycamore-derived antibacterial metabolite, 3 and $\mathbf{4}$ were more antibacterial against $F$. columnare ALM$00-173$ based on $24-\mathrm{h} \mathrm{IC}_{50}$ values of $2.13 \pm 0.11 \mathrm{mg} / \mathrm{L}$ and $2.62 \pm 0.23$ $\mathrm{mg} / \mathrm{L}$, respectively (Table 1). The mixture of all four isomers (Mix) also had similar activity, with a $24-\mathrm{h} \mathrm{IC}$ of $3.1 \pm 0.49 \mathrm{mg} / \mathrm{L}$. The RDCF and RDCO 24-h $\mathrm{IC}_{50}$ values also indicated the greatest activities of 3, 4, and Mix against $F$. columnare ALM-00-173, with RDCO values closer to "1.0" for 3 and 4 which indicates similar antibacterial activities of these isomers to oxytetracycline. Essentially, all four isomers and Mix had the same or similar MIC values $(7.47 \mathrm{mg} / \mathrm{L})$ when considering the standard error of the mean for 3 . The RDCF and RDCO MIC values indicate substantially weaker antibacterial activity for three isomers (1, 2 and 4) and Mix compared to the two drug controls while 3 had approximately one order of magnitude less antibacterial activity than the drug controls.

Evaluation of the four isomers and mixture of the isomers against E. ictaluri S02-1039 revealed no activity at the concentrations tested (Table 2). In addition, the four isomers and the mixture were also not antibacterial towards A. hydrophila HSB-B2 at test concentrations (Table 3). Therefore, the results demonstrate that these isomers do not possess broad-spectrum antibacterial activity towards species of Gramnegative, rod-shaped bacteria.

Based on $24-\mathrm{h} \mathrm{IC}_{50}$ results, Mix was slightly more antibacterial than any of the other individual four isomers against $S$. iniae LA94426 , with a value of $1.76 \pm 0.04 \mathrm{mg} / \mathrm{L}$ (Table 4 ). The $24-\mathrm{h} \mathrm{IC} \mathrm{C}_{50} \mathrm{RDCF}$ values indicate that the four isomers and Mix were only slightly less active against $S$. iniae LA94-426 than florfenicol, with values slightly above " 1 " and Mix with the lowest value at $1.2 \pm 0$. Conversely, the four isomers and Mix had 24-h $\mathrm{IC}_{50} \mathrm{RDCO}$ values more than an order of magnitude higher than the RDCF values which indicates substantially less activity than the drug control oxytetracycline. The MIC results show similar activities among the four isomers and Mix against $S$. iniae LA94-426, with a range of $4.11 \pm 3.36$ to $7.47 \pm 0 \mathrm{mg} / \mathrm{L}$. The MIC RDCF values indicate 3, 4, and Mix to be slightly more antibacterial than 1 and 2, but all four isomers and Mix were substantially less active than the drug controls.

The previous report on the antibacterial activities of the four isolated kaempferol isomers found them to be relatively inactive against the Gram-negative bacteria Escherichia coli and Pseudomonas aeruginosa [13]. However, the current results are the first to report of their antibacterial activities against the Gram-negative bacterium $F$. columnare. Also, this is the first report on their antibacterial activities against $S$. iniae. A similar range of antibacterial activities $\left(\mathrm{IC}_{50}\right.$ of 0.4 to $2.0 \mathrm{mg} / \mathrm{L}$ ) for $\mathbf{1}, \mathbf{2}, \mathbf{3}$, and $\mathbf{4}$ against MRSA, which is also a Grampositive, coccus, has been previously reported [13]. In addition, 4 was the most antibacterial among the four isomers against MRSA $\left(\mathrm{IC}_{50} 0.4 \mathrm{mg} / \mathrm{L}\right.$ ) which is similar to our results for $S$. iniae LA94-426 (Table 4). Apparently, the $Z$ configuration around the double bonds

\begin{tabular}{|c|c|c|c|c|c|c|}
\hline \multirow[b]{2}{*}{$\begin{array}{l}\text { Test } \\
\text { compound }\end{array}$} & \multirow[b]{2}{*}{$24-\mathrm{h} I C_{50}{ }^{a}$} & \multirow[b]{2}{*}{ MIC $^{b}$} & \multicolumn{2}{|l|}{ 24-h IC ${ }_{50}^{\text {a }}$} & \multicolumn{2}{|l|}{ MIC $^{b}$} \\
\hline & & & $\mathrm{RDCF}^{\mathrm{c}}$ & $\mathrm{RDCO}^{\mathrm{d}}$ & 24-h IC ${ }_{50}{ }^{c}$ & $M I C^{d}$ \\
\hline Flor* & $0.58(0.04)$ & $0.36(0)$ & & & & \\
\hline Oxy** & $0.86(0.07)$ & $0.46(0)$ & & & & \\
\hline 1 & $17.18(0.75)$ & $7.47(0)$ & $29.9(0.5)$ & $20.3(2.4)$ & $20.8(0)$ & $16.2(0)$ \\
\hline 2 & $6.91(3.55)$ & $7.47(0)$ & $12.4(6.9)$ & $7.8(3.6)$ & $20.8(0)$ & $16.2(0)$ \\
\hline 3 & $2.13(0.11)$ & $4.11(3.36)$ & $3.7(0)$ & $2.5(0.3)$ & $11.4(9.3)$ & $8.9(7.3)$ \\
\hline 4 & $2.62(0.23)$ & $7.47(0)$ & $4.6(0.1)$ & $3.1(0.5)$ & $20.8(0)$ & $16.2(0)$ \\
\hline Mix & $3.1(0.49)$ & $7.47(0)$ & $5.5(1.2)$ & $3.6(0.3)$ & $20.8(0)$ & $16.2(0)$ \\
\hline
\end{tabular}

*Florfenicol; **Oxytetracyline $\mathrm{HCl}$

a24-h $\mathrm{IC}_{50}=50 \%$ inhibition concentration in $\mathrm{mg} / \mathrm{L}$.

${ }^{\mathrm{b}} \mathrm{MIC}=$ Minimum inhibitory concentration in $\mathrm{mg} / \mathrm{L}$.

${ }^{\mathrm{C} R D C F}=$ Relative-to-drug-control florfenicol; values closer to 1.0 indicate higher antibacterial activity compared to florfenicol.

${ }^{\mathrm{d}} \mathrm{RDCO}=$ Relative-to-drug-control oxytetracycline; values closer to 1.0 indicate higher antibacterial activity compared to oxytetracycline.

Table 1: Results of the bioassay evaluation of antimicrobial compounds from American sycamore leaves for antibacterial activity against Flavobacterium columnare ALM-00-173. Numbers in parentheses are the standard error of the mean. 
Citation: Schrader KK, Hamann MT, McChesney JD, Rodenburg DL, Ibrahim MA (2015) Antibacterial Activities of Metabolites from Platanus occidentalis (American sycamore) against Fish Pathogenic Bacteria. J Aquac Res Development 6: 364. doi:10.4172/2155-9546.1000364

Page 4 of 4

\begin{tabular}{|c|c|c|c|c|c|c|}
\hline \multirow[b]{2}{*}{$\begin{array}{l}\text { Test } \\
\text { compound }\end{array}$} & \multirow[b]{2}{*}{ 24-h IC ${ }_{50}^{a}$} & \multirow[b]{2}{*}{$\mathrm{MIC}^{\mathrm{b}}$} & \multicolumn{2}{|c|}{ 24-h IC ${ }_{50}^{a}$} & \multicolumn{2}{|l|}{ MIC $^{b}$} \\
\hline & & & $\mathrm{RDCF}^{\mathrm{c}}$ & $\mathrm{RDCO}^{\mathrm{d}}$ & 24-h IC ${ }_{50}{ }^{c}$ & MIC $^{d}$ \\
\hline Flor* & $0.21(0.01)$ & $0.36(0)$ & & & & \\
\hline$O x y^{* *}$ & $0.1(0.01)$ & $0.05(0)$ & & & & \\
\hline 1 & $>74.7$ & $>74.7$ & $>373.5$ & $>747.0$ & $>207.5$ & $>149.4$ \\
\hline 2 & $>74.7$ & $>74.7$ & $>373.5$ & $>747.0$ & $>207.5$ & $>149.4$ \\
\hline 3 & $>74.7$ & $>74.7$ & $>373.5$ & $>747.0$ & $>207.5$ & $>149.4$ \\
\hline 4 & $>74.7$ & $>74.7$ & $>373.5$ & $>747.0$ & $>207.5$ & $>149.4$ \\
\hline Mix & $>74.7$ & $>74.7$ & $>373.5$ & $>747.0$ & $>207.5$ & $>149.4$ \\
\hline
\end{tabular}

*Florfenicol; **Oxytetracyline $\mathrm{HCl}$

a24-h IC $=50 \%$ inhibition concentration in $\mathrm{mg} / \mathrm{L}$.

${ }^{\mathrm{b}} \mathrm{MIC}=$ Minimum inhibitory concentration in $\mathrm{mg} / \mathrm{L}$.

${ }^{\mathrm{C}} \mathrm{RDCF}=$ Relative-to-drug-control florfenicol; values closer to 1.0 indicate higher antibacterial activity compared to florfenicol.

${ }^{\mathrm{d}} \mathrm{RDCO}=$ Relative-to-drug-control oxytetracycline; values closer to 1.0 indicate higher antibacterial activity compared to oxytetracycline.

Table 2: Results of the bioassay evaluation of antimicrobial compounds from American sycamore leaves for antibacterial activity against Edwardsiella ictaluri S02-1039. Numbers in parentheses are the standard error of the mean.

\begin{tabular}{|c|c|c|c|c|c|c|}
\hline \multirow[b]{2}{*}{ Test compound } & \multirow[b]{2}{*}{ 24-h IC ${ }_{50}^{a}$} & \multirow[b]{2}{*}{$M^{\prime} C^{b}$} & \multicolumn{2}{|c|}{ 24-h IC ${ }_{50}^{a}$} & \multicolumn{2}{|l|}{$\mathrm{MIC}^{\mathrm{b}}$} \\
\hline & & & $\mathrm{RDCF}^{\mathrm{c}}$ & $\mathrm{RDCO}^{\mathrm{d}}$ & 24-h IC ${ }_{50}^{c}$ & $M^{\prime} C^{d}$ \\
\hline Flor* & $0.18(0.14)$ & $0.36(0)$ & & & & \\
\hline$O x y^{* *}$ & $0.07(0.01)$ & $0.05(0)$ & & & & \\
\hline 1 & $>74.7$ & $>74.7$ & $>415.0$ & $>1067.1$ & $>207.5$ & $>1494.0$ \\
\hline 2 & $>74.7$ & $>74.7$ & $>415.0$ & $>1067.1$ & $>207.5$ & $>1494.0$ \\
\hline 3 & $>74.7$ & $>74.7$ & $>415.0$ & $>1067.1$ & $>207.5$ & $>1494.0$ \\
\hline 4 & $>74.7$ & $>74.7$ & $>415.0$ & $>1067.1$ & $>207.5$ & $>1494.0$ \\
\hline Mix & $>74.7$ & $>74.7$ & $>415.0$ & $>1067.1$ & $>207.5$ & $>1494.0$ \\
\hline
\end{tabular}

*Florfenicol; ** Oxytetracyline $\mathrm{HCl}$

a24-h $\mathrm{IC}_{50}=50 \%$ inhibition concentration in $\mathrm{mg} / \mathrm{L}$.

${ }^{\mathrm{b}} \mathrm{MIC}=$ Minimum inhibitory concentration in $\mathrm{mg} / \mathrm{L}$.

${ }^{\mathrm{C}} \mathrm{RDCF}=\mathrm{Relative-to-drug-control} \mathrm{florfenicol;}$ values closer to 1.0 indicate higher antibacterial activity compared to florfenicol.

${ }^{\mathrm{d}} \mathrm{RDCO}=$ Relative-to-drug-control oxytetracycline; values closer to 1.0 indicate higher antibacterial activity compared to oxytetracycline.

Table 3: Results of the bioassay evaluation of antimicrobial compounds from American sycamore leaves for antibacterial activity against Aeromonas hydrophila HSB-B2. Numbers in parentheses are the standard error of the mean.

\begin{tabular}{|c|c|c|c|c|c|c|}
\hline \multirow[b]{2}{*}{$\begin{array}{l}\text { Test } \\
\text { compound }\end{array}$} & \multirow[b]{2}{*}{ 24-h IC ${ }_{50}^{a}$} & \multirow[b]{2}{*}{ MIC $^{b}$} & \multicolumn{2}{|c|}{$24-\mathrm{h} I C_{50}{ }^{a}$} & \multicolumn{2}{|l|}{$\mathrm{MIC}^{\mathrm{b}}$} \\
\hline & & & $\mathrm{RDCF}^{\mathrm{c}}$ & $\mathrm{RDCO}^{\mathrm{d}}$ & $\mathrm{RDCF}^{\mathrm{c}}$ & $\mathrm{RDCO}^{\mathrm{d}}$ \\
\hline Flor* & $1.49(0.06)$ & $0.36(0)$ & & & & \\
\hline$O x y^{* *}$ & $0.12(0.02)$ & $0.46(0)$ & & & & \\
\hline 1 & $2.24(0.37)$ & $7.47(0)$ & $1.5(0.3)$ & $19.7(6.4)$ & $20.8(0)$ & $16.2(0)$ \\
\hline 2 & $2.1(0.08)$ & $7.47(0)$ & $1.4(0)$ & $17.9(2.4)$ & $20.8(0)$ & $16.2(0)$ \\
\hline 3 & $2.1(0.08)$ & $4.11(3.36)$ & $1.4(0)$ & $17.9(2.4)$ & $11.5(9.4)$ & $8.9(7.3)$ \\
\hline 4 & $1.87(0.23)$ & $4.11(3.36)$ & $1.3(0.2)$ & $16.3(4.6)$ & $11.5(9.4)$ & $8.9(7.3)$ \\
\hline Mix & $1.76(0.04)$ & $4.11(3.36)$ & $1.2(0)$ & $15.0(2.2)$ & $11.5(9.4)$ & $8.9(7.3)$ \\
\hline
\end{tabular}

*Florfenicol; ** Oxytetracyline $\mathrm{HCl}$

a24-h $\mathrm{IC}_{50}=50 \%$ inhibition concentration in $\mathrm{mg} / \mathrm{L}$.

${ }^{\mathrm{b}} \mathrm{MIC}=$ Minimum inhibitory concentration in $\mathrm{mg} / \mathrm{L}$.

${ }^{\mathrm{C}} \mathrm{RDCF}=$ Relative-to-drug-control florfenicol; values closer to 1.0 indicate higher antibacterial activity compared to florfenicol.

${ }^{\mathrm{d}} \mathrm{RDCO}=$ Relative-to-drug-control oxytetracycline; values closer to 1.0 indicate higher antibacterial activity compared to oxytetracycline.

Table 4: Results of the bioassay evaluation of antimicrobial compounds from American sycamore leaves for antibacterial activity against Streptococcus iniae LA94-426. Numbers in parentheses are the standard error of the mean

of the $p$-coumaroyl units as compared to the $E$ configuration plays an important role in the enhancement of the antibacterial activity of these compounds [13].

The bioassay evaluation of such natural compounds is the first step in the discovery of novel natural compounds to potentially be used in the management of columnaris disease and streptococcosis. Future studies of the four isomers include challenge studies in order to more fully evaluate the effectiveness of these compounds for disease management.

\section{Acknowledgement}

The authors thank Phaedra Page, Natural Products Utilization Research Unit, USDA-ARS, for technical assistance.

\section{References}

1. Wagner BA (2002) The epidemiology of bacterial diseases in food-size channel catfish. J Aquat Anim Health 14: 263-272.

2. Plumb JA, Hanson LA (2011) Health maintenance and principal microbial diseases of cultured fishes. (3rd edn), Wiley-Blackwell, Ames.

3. Durborow RM, Thune RL, Hawke JP, Camus AC (1998) Columnaris disease: a bacterial infection caused by Flavobacterium columnare. Southern Regional Aquaculture Center Publication No. 479, U.S. Department of Agriculture, Stoneville, Mississippi.

4. Harrell RM, Webster DW (1997) Striped bass and other Morone culture. Elsevier, Amsterdam.

5. Hiney M, Rodger H, Bricknell I, Casburn P, Mulcahy D (2002) Aquaculture development and regulation: incompatibility or harmony. Bull Eur Assn Fish P 25: 178-184.

6. Shoemaker CA, Klesius PH, Evans JJ (2001) Prevalence of Streptococcus iniae in tilapia, hybrid striped bass, and channel catfish on commercial fish farms in the United States. Am J Vet Res 62: 174-177.

7. Klesius P, Evans J, Shoemaker C (2006) A US perspective on advancements in fish vaccine development. Aquac Health Int 4: 20-21.

8. Plumb JA (1999) Health maintenance and principal microbial diseases of cultured fishes. lowa State University Press, Ames.

9. Boyd CE, Tucker CS (1998) Pond aquaculture water quality management, Kluwer Academic Publishers, Boston.

10. Darwish AM, Bebak JA, Schrader KK (2012) Assessment of Aquaflor ${ }^{\circledR}$, coppe sulphate and potassium permanganate for control of Aeromonas hydrophila and Flavobacterium columnare infection in sunshine bass, Morone chrysops female x Morone saxatilis male. J Fish Dis 35: 637-647.

11. Schrader KK, Harries MD, Darwish AM (2013) In vitro comparisons of the inhibitory activity of florfenicol, copper sulphate and potassium permanganate towards Aeromonas hydrophila and Flavobacterium columnare. Aquac Res 44 212-219.

12. Shoemaker CA, LaFrentz BR, Klesius PH, Evans JJ (2010) Protection against heterologous Streptococcus iniae isolates using a modified bacterin vaccine in Nile tilapia, Oreochromis niloticus (L.). J Fish Dis 33: 537-544.

13. Ibrahim MA, Mansoor AA, Gross A, Ashfaq MK, Jacob M, et al. (2009) Methicillin-resistant Staphylococcus aureus (MRSA)-active metabolites from Plantanus occidentalis (American sycamore). J Nat Prod 72: 2141-2144.

14. Decostere A, Henckaerts K, Haesebrouck F (2002) An alternative model to study the association of rainbow trout (Oncorhynchus mykiss L.) pathogens with the gill tissue. Lab Anim 36: 396-402.

15. Schrader KK, Harries MD (2006) A rapid bioassay for bactericides against the catfish pathogens Edwardsiella ictaluri and Flavobacterium columnare. Aquac Res 37: 928-937 